OPEN ACCESS

Edited by:

Maik Gollasch,

Charité Medical University of

Berlin, Germany

Reviewed by:

Rudolf Schubert,

Universität Heidelberg, Germany

Christian Aalkjaer,

Aarhus University, Denmark

*Correspondence:

Johanna Schleifenbaum

johanna.schleifenbaum@charite.de

Specialty section:

This article was submitted to Nephrology,

a section of the journal

Frontiers in Medicine

Received: 01 February 2019 Accepted: 23 May 2019

Published: 13 June 2019

Citation:

Zhong C and Schleifenbaum J (2019)

Genetically Encoded Calcium Indicators: A New Tool in Renal

Hypertension Research

Front. Med. 6:128

doi: 10.3389/fmed.2019.00128

\section{Genetically Encoded Calcium Indicators: A New Tool in Renal Hypertension Research}

\author{
Cheng Zhong and Johanna Schleifenbaum*
}

Institute of Vegetative Physiology, Charité-Universitätsmedizin Berlin, Corporate Member of Freie Universität Berlin, Humboldt-Universität zu Berlin, Berlin, Germany

Hypertension is ranked as the third cause of disability-adjusted life-years. The percentage of the population suffering from hypertension will continue to increase over the next years. Renovascular disease is one of the most common causes of secondary hypertension. Vascular changes seen in hypertension are partially based on dysfunctional calcium signaling. This signaling can be studied using calcium indicators (loading dyes and genetically encoded calcium indicators; GEC/s). Most progress in development has been seen in GECls, which are used in an increasing number of publications concerning calcium signaling in vasculature and the kidney. The use of transgenic mouse models expressing GECls will facilitate new possibilities to study dysfunctional calcium signaling in a cell type-specific manner, thus helping to identify more specific targets for treatment of (renal) hypertension.

Keywords: calcium, GCaMP, hypertension, kidney, imaging

\section{INTRODUCTION}

Hypertension, a disease with high incidence and a leading risk factor of mortality, is ranked as the third cause of disability-adjusted life-years (1). In particular, raised blood pressure is an important risk factor for cardiovascular diseases and chronic kidney disease. Worldwide, the estimated total number of adults with hypertension in 2000 was 972 million (26.4\% of the adult population) (2). The number of adults with raised blood pressure increased to 1.13 billion in 2015 , with the increase occurring largely in low-income and middle-income countries (3). The number of adults with hypertension in 2,025 is predicted to increase to a total of 1.56 billion (1.54-1.58 billion) (2). The most common causes of secondary, non-essential hypertension are renovascular disease, intrinsic renal disease, and primary hyperaldosteronism (4). These data show that hypertension is a global burden.

Calcium is one of the most important and multi-functional second messengers in cell biology, not only controlling contraction of the striated (5) and vascular smooth muscle, but also regulating cellular processes such as growth, proliferation, transcription, exocytosis, and apoptosis (6). Additionally, regulation of thick myofilament $\mathrm{Ca}^{2+}$ sensitivity, cytosolic $\mathrm{Ca}^{2+}$ induces conformational changes of thin filaments, which together determine actinmyosin and myocyte relaxation or constriction (7). Vascular smooth muscle cell (VSMC) contraction is initiated by an increase in the global intracellular calcium $\left(\left[\mathrm{Ca}^{2+}\right] \mathrm{i}\right)$ concentration, which is caused by an opening of voltage-gated calcium channels, particularly L-type Cav1.2 channels (8). Importantly, the VSMCs' phenotype can switch in cardiovascular disease. For example, de-differentiation of the VSMCs is associated with a shift of the 
expression of $\mathrm{Ca}^{2+}$ channels from voltage-gated to voltageinsensitive $\mathrm{Ca}^{2+}$ channels (9). In addition, $\mathrm{Ca}^{2+}$ entry in non-contractile (dedifferentiated) VSMCs occurs predominantly via store-operated $\mathrm{Ca}^{2+}$ entry (SOCE) and receptor-operated $\mathrm{Ca}^{2+}$ entry (ROCE) pathways. These changes may have physiological importance for normal smooth muscle function and may influence VSMC behavior under pathophysiological conditions (9). With age, reactivity of small arteries is lowered. This is followed by alterations of arterial stiffness, arterial wall thickening, and a reduced myogenic responsiveness, thus increasing total peripheral resistance $(10,11)$. Calcium antagonists (e.g., L-type channel inhibitors) are often used as anti-hypertensive drugs. Since the reasons for dedifferentiation of VSMCs are poorly understood (12), it is important to identify calcium signaling pathways in VSMCs in hypertension and cardiovascular disease and determine their functions, which may ultimately lead to new drug targets.

\section{CALCIUM INDICATORS: LOADING DYES, FUSION PROTEINS, AND GENETICALLY MODIFIED GECIs}

Calcium imaging of living tissue has turned out to be a useful tool for the investigation of different intracellular calcium signals. Fluorescent free calcium-binding dyes such as Fura-2 enabled a first visualization of intracellular calcium upon loading of the tissue (13). Fura-2 is still one of the most frequently used ratiometric $\mathrm{Ca}^{2+}$ indicators. It is excited at two different wavelengths. The $\mathrm{Ca}^{2+}$ unbound form of Fura- 2 is excited at $380 \mathrm{~nm}$ and the $\mathrm{Ca}^{2+}$ bound form at $340 \mathrm{~nm}$. The emitted light is measured at around $510 \mathrm{~nm}$ (14). Thus, the intensity of the emitted fluorescence light changes depending on the calcium ion concentration, while a high spatial resolution can be reached. Although low temporal resolution can be a problem for recording of fast $\mathrm{Ca}^{2+}$ transients, such as $\mathrm{Ca}^{2+}$ sparks in VSMCs $(14,15)$, a major disadvantage of loading dyes such as Fura-2 is a possible uneven tissue distribution of the dye as well as loading of cell structures not intended for investigation (16).

Genetically encoded $\mathrm{Ca}^{2+}$ indicators (GECIs) show a huge progress for imaging to solve poor selectivity and disadvantages of loading dyes into the cytosol before measurement (Table 2). The first protein-based $\mathrm{Ca}^{2+}$ indicator was photoprotein aequorin, purified from jellyfish Aequorea Victoria, injected into cells in the early 1970s (17). After cloning of its cDNA, recombinant aequorin became the most frequently used probe to measure intracellular $\mathrm{Ca}^{2+}$. Another important step was the advancement of a green fluorescent protein (GFP), which enabled the investigation of the spatio-temporal distribution of proteins in living cells, through the formation of fused protein-GFP structures. This coupling meant a co-expression of GFP upon target protein expression, thus marking the protein via fluorescence (18-21) (Table 1). GECIs are subject to photobleaching after extended excitation, although usually less than loading dyes (29). Thus, complex photobleaching curves have to be considered when analyzing obtained data. The probe insensitivity to $\mathrm{Mg}^{2+}$ is an important issue, because changes
TABLE 1 | Classes of genetically encoded calcium indicators (GECls).

\begin{tabular}{|c|c|c|}
\hline Class & Composition & References \\
\hline 1 & $\begin{array}{l}\text { - Bioluminescent reporters based on aequorin } \\
\text { photoprotein (e.g., GFP) } \\
\text { - Light generated by a chemical reaction requiring } \\
\text { reconstitution of the indicator with a co-factor }\end{array}$ & $(22,23)$ \\
\hline 2 & $\begin{array}{l}\text { - Based on single fluorescent proteins (e.g., GCaMP) } \\
\text { - Calcium-responsive elements as calmodulin (CaM) (or } \\
\text { parts of it) inserted into fluorescent protein; calcium } \\
\text { binding alters protonation state, conformation, and } \\
\text { spectral chromophore properties }\end{array}$ & $(24,25)$ \\
\hline 3 & $\begin{array}{l}\text { - "Cameleon"-type } \\
\text { - Calcium-responsive elements between two fluorescent } \\
\text { proteins; calcium binding alters efficiency of } \\
\text { fluorescence resonance energy transfer (FRET) }\end{array}$ & $(26-28)$ \\
\hline
\end{tabular}

TABLE 2 | Advantages of genetically encoded indicators (GECls).

\begin{tabular}{lll}
\hline $\begin{array}{l}\text { Major } \\
\text { advantages }\end{array}$ & Explanation & Reference \\
\hline Accurate location & $\begin{array}{l}\text { Monitoring activity among genetically } \\
\text { defined subsets of cells, i.e., targeted } \\
\text { to specific cell types } \\
\text { Measuring calcium dynamics in specific } \\
\text { subcellular compartments } \\
\text { Long-term calcium imaging in vivo and } \\
\text { imaging in a relatively non-invasive } \\
\text { manner }\end{array}$ \\
\hline
\end{tabular}

of $\mathrm{Mg}^{2+}$ concentration can trigger cell activation. Inaccurate intracellular location is also another issue to be solved using GECIs. A kind of larger dynamic range, robust photonic and thermal stability $\mathrm{Ca}^{2+}$ probe is needed. (30) Furthermore, oligomerization is another adverse property of GFP. Therefore, mutagenesis approaches are needed to recover the functional expression of monomeric forms of GFP (31) (Tables 2, 3).

GFP is used as scaffolding for the most recent fluorescent calcium indicators, namely genetically encoded calcium indicators (GECIs) like GCaMP (26). In those proteins, circularly permuted forms of GFP are fused to calmodulin (CaM) and the M13 domain of the myosin light chain kinase (MLCK). The latter is able to bind CaM. If calcium ions are present, GCaMP changes its conformation due to calcium binding to CaM (Figure 1). This leads to a bright fluorescence through a rapid deprotonation of the chromophore (26).

GECIs can be used not only for $\mathrm{Ca}^{2+}$ imaging in the cytosol but also in subcellular compartments, i.e., in a wide spectrum of organelles. Among them, the GCaMP6f probe targeted to mitochondria (4mtGCaMP) has been recently developed to measure mitochondrial calcium levels (39). Other protocols of using GECIs have been developed for $\mathrm{Ca}^{2+}$ imaging in the nucleus and endoplasmic reticulum (40,41). Importantly, the fluorescent indicators' brightness could be problematic for $\mathrm{Ca}^{2+}$ imaging in organelles because of the acidic environment which can affect fluorescence; therefore, specific tasks, e.g., "chameleon" type indicators, have been developed for target 
TABLE 3 | Limitations of genetically encoded indicators (GECIs).

\begin{tabular}{ll}
\hline Major limitations & Explanation \\
\hline Sensor signal strength & $\begin{array}{l}\text { 1. Chameleons' molecules exhibit limited in vivo signal } \\
\text { strength }\end{array}$ \\
$\begin{array}{l}\text { 2. Endogenous calmodulin would decrease probe signal } \\
\text { strength }\end{array}$ & $\begin{array}{l}\text { 3. Low expression: often resulting in sensors' inactivation or } \\
\text { reduced dynamic range }\end{array}$ \\
Thermal instability: temperature-dependent structure shifts \\
may markedly alter fluorescent properties resulting in poor \\
visualization or signally properties in in vivo experiments \\
Change of Ca $2+$ concentration affects fluorescence on and \\
off rates; limited sensitivity and slow response kinetics \\
Covalent modulation of calmodulin or binding to endogenous \\
targets will be eliminated; can be susceptible to effects of \\
Interaction between the
\end{tabular}

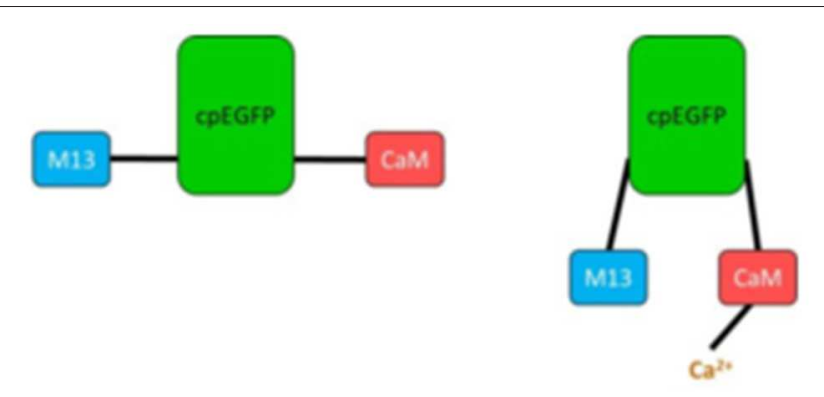

FIGURE 1 | Simplified scheme of GCaMP unbound (Left) and bound to $\mathrm{Ca}^{2+}$ (Right). M13, fragment of myosin light chain kinase; cpEGFP, circularly permuted enhanced GFP; CaM, calmodulin.

locations in different organelles to detect $\mathrm{Ca}^{2+}$ release (42). The fluorescent indicators mentioned above emit green fluorescence. Notably, there are also modified variants of GFP using different fluorescence spectra. Known fluorescence examples include RFP (red fluorescence) (43), YFP (yellow fluorescence) $(44,45)$, or CFP (cyan fluorescence) $(46,47)$. The modifications also provide the basis for GECIs as RCaMP (red fluorescence) (48), YCaMP (yellow fluorescence) (48), or CyCaMP (cyan fluorescence) (48). Different color channels allows for the imaging of tissues already expressing GFP, as well as the reduction of autofluorescence compared to GCaMP or loading dyes.

Genetically encoded calcium indicators (GECIs) can be divided into three different classes (Table 1) (49), two of them have just been described. Class 3 indicators ("chameleon"-type sensors) contain two fluorescent proteins and are applied to measurements involving fluorescent resonance energy transfer (FRET).

\section{VASCULAR EXPRESSION OF GCaMP INDICATORS}

One huge advantage of GCaMP is the possibility of cell typespecific expression. It can be coupled to a promoter only expressed in the cell type of interest, so activation of this promoter leads to co-expression of GCaMP. Many studies involving GCaMP have been done in neuronal tissue (5052), but vascular applications are possible, for example, using mice expressing GCaMP only in acta 2-positive cells (SMCspecific fluorescence), or in connexin 40 (Cx40)-positive cells (endothelial-specific fluorescence) (53-57). Not only can the expression of the protein be detected (as with GFP), but changes in fluorescence intensity reflecting changes in the calcium concentration can also be detected. If GCaMP is co-expressed with another fluorescent protein using other wavelength spectra, e.g., red fluorescent mCherry, a ratio of those two fluorescent proteins can be used for quantification of the intracellular calcium concentration. But expression levels of transgenes show considerable animal-to-animal variation, complicating the analysis of imaging results, and so linearizing the imaging measurement and background in high pixels is needed (58). As GCaMP sensors are stable at mammalian body temperatures, they can also be used for in vivo recordings of calcium signaling. GCaMP molecules have been modified and improved on since their first development, allowing higher spatio-temporal resolution, higher sensitivity, and more rapid off kinetics. GCaMP expression even allows calcium imaging of subcellular structures such as a nucleus, endoplasmic reticulum, and mitochondria (57). There is also a review available specifically on the application of GCaMP in cardiomyocytes (59).

\section{GCaMP INDICATORS IN KIDNEY SLICES}

In the vasculature, the above-mentioned $\mathrm{Cx} 40$ serves as an endothelial-specific marker protein, enabling cell type-specific calcium imaging. In the kidney, $\mathrm{Cx} 40$ was found to be abundantly expressed in specialized SMCs of the juxtaglomerular apparatus (JGA), namely renin-producing granular cells (60). The cells contribute to the tone of afferent arteriole and control of renin synthesis and release. Both processes rely on calcium signals $(61,62)$, which are positively correlated with renin secretion (63) without the involvement of voltage-gated $\mathrm{Ca}^{2+}$ channels (64). Interestingly, these cells contain, in addition to the secretory granules, contractile proteins, which are arranged in a sublemmal network. A paradoxical (inhibitory) role of intracellular calcium 


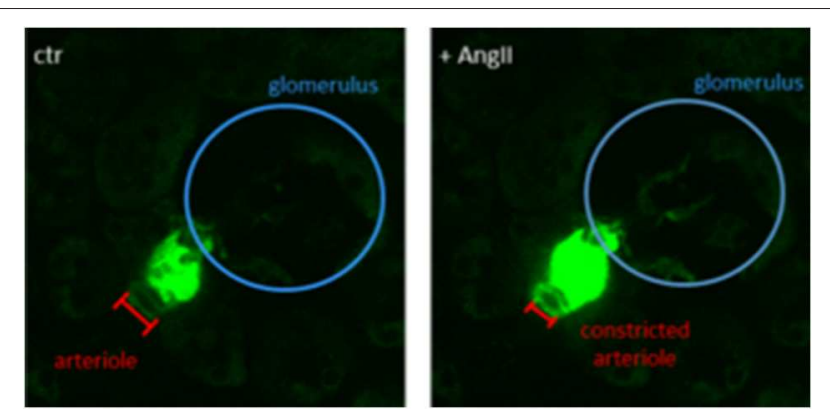

FIGURE 2 | Single frame of a Cx40-GCaMP kidney slice recording. Left: Spontaneous calcium transients in Cx40-positive renin-producing granular cells (green). Right: Increased calcium signal after treatment with angiotensin II (Angll, $100 \mathrm{nM}$ ). Afferent arteriole is constricted upon Angll treatment.

in renin secretion could be explained by an increased tone of this sublemmal network, which might impair the pre-exocytotic access of renin granules to the cell membrane (65).

Cx40, a gap junction protein, coordinates propagating signals between individual cells, thus $\mathrm{Cx} 40$-positive cells expressing a GCaMP sensor are valuable for studying propagating calcium signals in connected cells and tissues, respectively. Propagating calcium transients can be observed using an in-situ kidney slice model of Cx40-GCaMP mice, as shown in Figure 2. The slices already show spontaneous intracellular calcium transients without any treatment. Upon treatment with angiotensin II (AngII), the $\mathrm{Ca}^{2+}$ transients are elevated (Figure 2). Characterizing the spontaneous signals and comparing them to AngII-induced transients might be of great interest for (1) studying the control of afferent arteriole tone and renin release and (2) explore potential coupling of the signals regulating both processes.

GCaMP sensors have already been used in the kidney to study calcium signals in podocytes. Pathological changes of the glomerular filtration barrier have been linked to elevated intracellular calcium concentrations in podocytes (66). Signals could be measured in vivo using GCaMP sensors

\section{REFERENCES}

1. Ezzati M, Lopez AD, Rodgers A, Vander Hoorn S, Murray CJ. Selected major risk factors and global and regional burden of disease. Lancet. (2002) 360:1347-60. doi: 10.1016/S0140-6736(02)11403-6

2. Kearney PM, Whelton M, Reynolds K, Muntner P, Whelton PK, He J. Global burden of hypertension: analysis of worldwide data. Lancet. (2005) 365:217-23. doi: 10.1016/S0140-6736(05)70151-3

3. NCD Risk Factor Collaboration. Worldwide trends in blood pressure from 1975 to 2015: a pooled analysis of 1479 population-based measurement studies with 19.1 million participants. Lancet. (2017) 389:37-55. doi: 10.1016/S0140-6736(16)31919-5

4. Pullalarevu R, Akbar G, Teehan G. Secondary hypertension, issues in diagnosis and treatment. Primary care. (2014) 41:749-64. doi: 10.1016/j.pop.2014.08.001

5. Schneider MF. Control of calcium release in functioning skeletal muscle fibers. Annu Rev Physiol. (1994) 56:463-84. doi: 10.1146/annurev.ph.56.030194.002335 in podocin-positive cells (Pod-GCaMP3), providing podocytespecific fluorescence (67).

\section{SUMMARY}

The ongoing development of genetically modified calcium indicators provides great opportunities for studying calcium signaling in specific cell types and organs linked to the development of hypertension, e.g., in vasculature and kidneys. The improvement of the sensors allows a higher spatio-temporal resolution and a higher sensitivity for qualitative as well as quantitative measurements. Different excitation wavelengths enable simultaneous recordings of calcium signals in different colors, and thus a differentiation of parallel signals in different locations (e.g., SMCs and ECs).

Mice expressing GECIs in a cell type-specific manner can be subject to hypertension-inducing treatments (administration of AngII, or L-NAME), allowing exploration of calcium signaling changes in vasculature and organs such as the kidneys, in comparison to healthy control animals. The effects of different drugs influencing intracellular calcium signaling can be studied in vivo as well as in situ and can help in finding new therapeutic targets to reverse dysfunctional calcium signaling under hypertensive conditions in vasculature and kidneys. Thus, animal models expressing GCaMP sensors will play an important role in the future of renal hypertension research.

\section{AUTHOR CONTRIBUTIONS}

All authors listed have made a substantial, direct and intellectual contribution to the work, and approved it for publication.

\section{FUNDING}

This work is supported by the Deutsche Forschungsgemeinschaft (DFG). CZ is funded by a research fellowship from Guiyang Sunshine Hospital; Guiyang, China. We acknowledge support from the Open Access Publication Fund of Charité-Universitätsmedizin Berlin.

6. Berridge MJ, Bootman MD, Roderick HL. Calcium signalling: dynamics, homeostasis and remodelling. Nat Rev Mol Cell Biol. (2003) 4:517-29. doi: 10.1057/9780230501348_10

7. Bers DM. Cardiac excitation-contraction coupling. Nature. (2002) 415:198205. doi: 10.1038/415198a

8. Knot HJ, Nelson MT. Regulation of arterial diameter and wall $[\mathrm{Ca} 2+]$ in cerebral arteries of rat by membrane potential and intravascular pressure. J Physiol. (1998) 508(Pt 1):199-209. doi: 10.1111/j.1469-7793.1998. 199br.x

9. Gollasch M, Haase H, Ried C, Lindschau C, Morano I, Luft FC, et al. L-type calcium channel expression depends on the differentiated state of vascular smooth muscle cells. FASEB J. (1998) 12:593-601. doi: 10.1096/fasebj.12.7.593

10. Sehgel NL, Sun Z, Hong Z, Hunter WC, Hill MA, Vatner DE, et al. Augmented vascular smooth muscle cell stiffness and adhesion when hypertension is superimposed on aging. Hypertension. (2015) 65:370-7. doi: 10.1161/HYPERTENSIONAHA.114.04456

11. Sun Z, Aging, arterial stiffness, and hypertension. Hypertension. (2015) 65:252-6. doi: 10.1161/HYPERTENSIONAHA.114.03617 
12. Matchkov VV, Kudryavtseva O, Aalkjaer C. Intracellular Ca2+ signalling and phenotype of vascular smooth muscle cells. Basic Clin Pharmacol Toxicol. (2011) 110:42-8. doi: 10.1111/j.1742-7843.2011.00818.x

13. Grynkiewicz G, Poenie M, Tsien RY, A new generation of $\mathrm{Ca} 2+$ indicators with greatly improved fluorescence properties. J Biol Chem. (1985) 260:344050 .

14. So PTC, French T, Yu WM, Berland KM, Dong CY, Gratton E. Timeresolved fluorescence microscopy using two-photon excitation. Bioimaging. (1995) 3:49-63.

15. Nelson MT, Cheng H, Rubart M, Santana LF, Bonev AD, Knot HJ, et al. Relaxation of arterial smooth muscle by calcium sparks. Science. (1995) 270:633-7. doi: 10.1126/science.270.5236.633

16. Paredes RM, Etzler JC, Watts LT, Zheng W, Lechleiter JD. Chemical calcium indicators. Methods. (2008) 46:143-51. doi: 10.1016/j.ymeth.2008.09.025

17. Shimomura O. A short story of aequorin. Biol Bull. (1995) 189:1-5. doi: $10.2307 / 1542194$

18. Arun KH, Kaul CL, Ramarao P. Green fluorescent proteins in receptor research: an emerging tool for drug discovery. J Pharmacol Toxicol Methods. (2005) 51:1-23. doi: 10.1016/j.vascn.2004.07.006

19. Jugder BE, Welch J, Braidy N, Marquis CP. Construction and use of a Cupriavidus necator $\mathrm{H} 16$ soluble hydrogenase promoter (PSH) fusion to gfp (green fluorescent protein). PeerJ. (2016) 4:e2269. doi: 10.7717/peerj.2269

20. Inouye S, Noguchi M, Sakaki Y, Takagi Y, Miyata T, Iwanaga S, et al. Cloning and sequence analysis of cDNA for the luminescent protein aequorin. Proc Natl Acad Sci USA. (1985) 82:3154-8. doi: 10.1073/pnas.82.10.3154

21. Shimomura O, Johnson FH, Saiga Y, Extraction, purification and properties of aequorin, a bioluminescent protein from the luminous hydromedusan, Aequorea. J Cell Compar Physiol. (1962) 59:223-39. doi: $10.1002 /$ jcp. 1030590302

22. Rizzuto R, Brini M, Pozzan T. Targeting recombinant aequorin to specific intracellular organelles. Methods Cell Biol. (1994) 40:339-58. doi: 10.1016/S0091-679X(08)61121-8

23. Robert V, Pinton P, Tosello V, Rizzuto R, Pozzan T. Recombinant aequorin as tool for monitoring calcium concentration in subcellular compartments. Methods Enzymol. (2000) 327:440-56. doi: 10.1016/S0076-6879(00) 27295-9

24. Ohkura M, Matsuzaki M, Kasai H, Imoto K, Nakai J. Genetically encoded bright $\mathrm{Ca} 2+$ probe applicable for dynamic $\mathrm{Ca} 2+$ imaging of dendritic spines. Analyt Chem. (2005) 77:5861-9. doi: 10.1021/ac0506837

25. Tallini YN, Ohkura M, Choi BR, Ji G, Imoto K, Doran R, et al. Imaging cellular signals in the heart in vivo: Cardiac expression of the high-signal Ca2+ indicator GCaMP2. Proc Natl Acad Sci USA. (2006) 103:4753-8. doi: 10.1073/pnas.0509378103

26. Miyawaki A, Llopis J, Heim R, McCaffery JM, Adams JA, Ikura M, Tsien RY. Fluorescent indicators for $\mathrm{Ca} 2+$ based on green fluorescent proteins and calmodulin. Nature. (1997) 388:882-7. doi: 10.1038/42264

27. Palmer AE, Giacomello M, Kortemme T, Hires SA, Lev-Ram V, Baker D, et al. $\mathrm{Ca} 2+$ indicators based on computationally redesigned calmodulin-peptide pairs. Chem Biol. (2006) 13:521-30. doi: 10.1016/j.chembiol.2006.03.007

28. Palmer AE, Jin C, Reed JC, Tsien RY. Bcl-2-mediated alterations in endoplasmic reticulum $\mathrm{Ca} 2+$ analyzed with an improved genetically encoded fluorescent sensor. Proc Natl Acad Sci USA. (2004) 101:17404-9. doi: 10.1073/pnas.0408030101

29. Niswender KD, Blackman SM, Rohde L, Magnuson MA, Piston DW. Quantitative imaging of green fluorescent protein in cultured cells: comparison of microscopic techniques, use in fusion proteins and detection limits. J Microscopy. (1995) 180:109-16. doi: 10.1111/j.1365-2818.1995.tb03665.x

30. Rodriguez-Garcia A, Rojo-Ruiz J, Navas-Navarro P, Aulestia FJ, GallegoSandin S, Garcia-Sancho J, Alonso MT. GAP, an aequorin-based fluorescent indicator for imaging Ca2+ in organelles. Proc Natl Acad Sci USA. (2014) 111:2584-9. doi: 10.1073/pnas.1316539111

31. Kredel S, Oswald F, Nienhaus K, Deuschle K, Rocker C, Wolff M, et al. mRuby, a bright monomeric red fluorescent protein for labeling of subcellular structures. PLoS ONE. (2009) 4:e4391. doi: 10.1371/journal.pone.0004391

32. K. MI, Genetically encoded Ca2+ indicators: using genetics and molecular design to understand complex physiology. J Physiol. (2007) 578:55-67. doi: 10.1113/jphysiol.2006.120212
33. Reiff DF, Ihring A, Guerrero G, Isacoff EY, Joesch M, Nakai J, Borst A. In vivo performance of genetically encoded indicators of neural activity in flies. $J$ Neurosci. (2005) 25:4766-78. doi: 10.1523/JNEUROSCI.4900-04.2005

34. Mank M, Reiff DF, Heim N, Friedrich MW, Borst A, Griesbeck O. A FRETbased calcium biosensor with fast signal kinetics and high fluorescence change. Biophys J. (2006) 90:1790-6. doi: 10.1529/biophysj.105.073536

35. Takahashi N, Kimura R, Tachikawa A, Miwa A, Okado H, Miyashita Y, et al. Two-photon excitation imaging of pancreatic islets with various fluorescent probes. Diabetes. (2002) S25-8. doi: 10.2337/diabetes.51.2007.S25

36. Eberhard M, Erne P. Kinetics of calcium binding to fluo-3 determined by stopped-flow fluorescence. Biochem Biophys Res Commun. (1989) 163:309-14. doi: 10.1016/0006-291X(89)92136-0

37. Eberhard M, Erne P. Calcium binding to fluorescent calcium indicators: calcium green, calcium orange and calcium crimson. Biochem Biophys Res Commun. (1991) 180:209-15. doi: 10.1016/S0006-291X(05)81278-1

38. Anderson $M$, Zheng Q, Dong $X$. Investigation of pain mechanisms by calcium imaging approaches. Neurosci Bull. (2018) 34:194-9. doi: 10.1007/s12264-017-0139-9

39. Vicario M, Cali T. Measuring $\mathrm{Ca}(2+)$ levels in subcellular compartments with genetically encoded GFP-based indicators. Methods Mol Biol. (2019) 1925:31-42. doi: 10.1007/978-1-4939-9018-4_3

40. Park JG, Palmer AE. Properties and use of genetically encoded FRET sensors for cytosolic and organellar Ca2+ measurements. Cold Spring Harb Protoc. (2015) 2015:pdb top066043. doi: 10.1101/pdb.top066043

41. Park JG, Palmer AE. Verifying the function and localization of genetically encoded $\mathrm{Ca} 2+$ sensors and converting FRET ratios to $\mathrm{Ca} 2+$ concentrations. Cold Spring Harb Protoc. (2015) 2015:pdb prot076547. doi: 10.1101/pdb.prot076547

42. Suzuki J, Kanemaru K, Iino M. Genetically encoded fluorescent indicators for organellar calcium imaging. Biophys J. (2016) 111:1119-31. doi: 10.1016/j.bpj.2016.04.054

43. Matz MV, Fradkov AF, Labas YA, Savitsky AP, Zaraisky AG, Markelov ML, et al. Fluorescent proteins from nonbioluminescent Anthozoa species. Nat Biotechnol. (1999) 17:969-73. doi: 10.1038/13657

44. Daubner SC, Astorga AM, Leisman GB, Baldwin TO. Yellow light emission of vibrio fischeri strain Y-1: purification and characterization of the energyaccepting yellow fluorescent protein. Proc Natl Acad Sci USA. (1987) 84:89126. doi: $10.1073 /$ pnas.84.24.8912

45. Ormo M, Cubitt AB, Kallio K, Gross LA, Tsien RY, Remington SJ. Crystal structure of the Aequorea victoria green fluorescent protein. Science. (1996) 273:1392-5. doi: 10.1126/science.273.5280.1392

46. Miller DM, 3rd, Desai NS, Hardin DC, Piston DW, Patterson GH, Fleenor J, et al. Two-color GFP expression system for C. elegans. BioTech. (1999) 26:920-1. doi: 10.2144/99265rr01

47. Heim R, Tsien RY. Engineering green fluorescent protein for improved brightness, longer wavelengths and fluorescence resonance energy transfer. Curr Biol. (1996) 6:178-82. doi: 10.1016/S0960-9822(02)00450-5

48. Akerboom J, Carreras Calderon N, Tian L, Wabnig S, Prigge M, Tolo J, et al. Genetically encoded calcium indicators for multi-color neural activity imaging and combination with optogenetics. Front Mol Neurosci. (2013) 6:2. doi: $10.3389 /$ fnmol.2013.00002

49. McCombs JE, Palmer AE. Measuring calcium dynamics in living cells with genetically encodable calcium indicators. Methods. (2008) 46:152-9. doi: 10.1016/j.ymeth.2008.09.015

50. Hires SA, Tian L, Looger LL. Reporting neural activity with genetically encoded calcium indicators. Brain Cell Biol. (2008) 36:69-86. doi: 10.1007/s11068-008-9029-4

51. Tian L, Akerboom J, Schreiter ER, Looger LL. Neural activity imaging with genetically encoded calcium indicators. Progress Brain Res. (2012) 196:79-94. doi: 10.1016/B978-0-444-59426-6.00 005-7

52. Tian L, Hires SA, Looger LL. Imaging neuronal activity with genetically encoded calcium indicators. Cold Spring Harbor protocols. (2012) 2012:64756. doi: 10.1101/pdb.top069609

53. Ledoux J, Taylor MS, Bonev AD, Hannah RM, Solodushko V, Shui B, et al. Functional architecture of inositol 1,4,5-trisphosphate signaling in restricted spaces of myoendothelial projections. Proc Natl Acad Sci USA. (2008) 105:9627-32. doi: 10.1073/pnas.0801963105 
54. Nausch LW, Bonev AD, Heppner TJ, Tallini Y, Kotlikoff MI, Nelson MT. Sympathetic nerve stimulation induces local endothelial $\mathrm{Ca} 2+$ signals to oppose vasoconstriction of mouse mesenteric arteries. Am J Physiol Heart Circ Physiol. (2012) 302:H594-602. doi: 10.1152/ajpheart.00773.2011

55. Nelson M, Ledoux J, Taylor M, Bonev A, Hannah R, Solodushko V, et al. Spinning disk confocal microscopy of calcium signalling in blood vessel walls. Microscopy Anal. (2010) 24:5-8.

56. Tallini YN, Brekke JF, Shui B, Doran R, Hwang SM, Nakai J, et al. Propagated endothelial $\mathrm{Ca} 2+$ waves and arteriolar dilation in vivo: measurements in Cx40BAC GCaMP2 transgenic mice. Circul Res. (2007) 101:1300-9. doi: 10.1161/CIRCRESAHA.107.149484

57. Shui B, Lee JC, Reining S, Lee FK, Kotlikoff MI. Optogenetic sensors and effectors: CHROMus-the cornell heart lung blood institute resource for optogenetic mouse signaling. Front Physiol. (2014) 5:428. doi: 10.3389/fphys.2014.00428

58. Akerboom J, Chen TW, Wardill TJ, Tian L, Marvin JS, Mutlu S, et al. Optimization of a GCaMP calcium indicator for neural activity imaging. $J$ Neurosci. (2012) 32:13819-40. doi: 10.1523/JNEUROSCI.2601-12.2012

59. Kaestner L, Scholz A, Tian Q, Ruppenthal S, Tabellion W, Wiesen K, et al. Genetically encoded Ca2+ indicators in cardiac myocytes. Circul Res. (2014) 114:1623-39. doi: 10.1161/CIRCRESAHA.114.303475

60. Abed AB, Kavvadas P, Chadjichristos CE. Functional roles of connexins and pannexins in the kidney. Cell Mol Life Sci. (2015) 72:2869-77. doi: 10.1007/s00018-015-1964-5

61. Steppan D, Pan L, Gross KW, Kurtz A. Analysis of the calcium paradox of renin secretion. Am J Physiol. Renal physiol. (2018) 315:F834-f843. doi: 10.1152/ajprenal.00554.2017

62. Navar LG. Integrating multiple paracrine regulators of renal microvascular dynamics. Am J Physiol. (1998) 274:F433-44. doi: 10.1152/ajprenal.1998.274.3.F433
63. Skott O, Jensen BL. Cellular and intrarenal control of renin secretion. Clin Sci. (1993) 84:1-10. doi: 10.1042/cs0840001

64. Kurtz SA, Chegini S, Penner R. Lack of direct evidence for a functional role of voltageoperated calcium channels in juxtaglomerular cells. Pfliigen Arch. (1990) 416:281-7. doi: 10.1007/BF00392064

65. Taugner R, Nobiling R, Metz R, Taugner F, Buhrle C, Hackenthal E. Hypothetical interpretation of the calcium paradox in renin secretion. Cell Tissue Res. (1988) 252:687-90. doi: 10.1007/BF00 216658

66. Greka, Mundel P. Balancing calcium signals through TRPC5 and TRPC6 in podocytes. J Am Soc Nephrol. (2011) 22:1969-80. doi: 10.1681/ASN.2011040370

67. Burford JL, Villanueva K, Lam L, Riquier-Brison A, Hackl MJ, Pippin J, et al. Intravital imaging of podocyte calcium in glomerular injury and disease. J Clin Invest. (2014) 124:2050-8. doi: 10.1172/JCI71702

Conflict of Interest Statement: The authors declare that the research was conducted in the absence of any commercial or financial relationships that could be construed as a potential conflict of interest.

The handling Editor declared shared affiliations, though no other collaboration on this topic or techniques, with both of the authors.

Copyright (C) 2019 Zhong and Schleifenbaum. This is an open-access article distributed under the terms of the Creative Commons Attribution License (CC BY). The use, distribution or reproduction in other forums is permitted, provided the original author(s) and the copyright owner(s) are credited and that the original publication in this journal is cited, in accordance with accepted academic practice. No use, distribution or reproduction is permitted which does not comply with these terms. 